\section{Exogenous Gibberellic Acid and Cytokinin Effects on Budbreak, Flowering, and Yield of Blackberry Grown under Subtropical Climatic Conditions}

\author{
Syuan-You Lin and Shinsuke Agehara \\ Gulf Coast Research and Education Center, Institute of Food and \\ Agricultural Sciences, University of Florida, 14625 CR 672, Wimauma, FL \\ 33598
}

Additional index words. Bramble, dormancy, flower abortion, plant growth regulator, Rubus

Abstract. In subtropical climates, inadequate winter chill limits blackberry (Rubus $\mathbf{L}$. subgenus Rubus Watson) production by causing poor and erratic floral budbreak. To compensate for a lack of chilling, bud dormancy-breaking agents must be developed for subtropical blackberry production. Our previous study showed that gibberellic acid $\left(\mathrm{GA}_{3}\right)$ promotes budbreak in three blackberry cultivars but has potential negative side effects on floral development in 'Natchez'. 6-benzyladenine (6-BA) is a synthetic cytokinin that can act as an antagonist of gibberellins during floral transition. The objectives of this study were to evaluate cultivar $\times$ exogenous $\mathbf{G A}_{3}$ interactions, characterize dose effects of exogenous $\mathbf{G A}_{3}$, and examine synergistic effects of $\mathbf{G A}_{3}$ and 6-BA. Three field experiments were conducted in west central Florida. All spray treatments were applied at the end of the chilling period. In the first experiment, 'Natchez', 'Navaho', and 'Ouachita' were treated with $\mathbf{G A}_{3}$ at 0 or $99 \mathrm{~g} \cdot \mathrm{ha}^{-1}$. Budbreak was promoted by exogenous $\mathrm{GA}_{3}$ in all three cultivars $(0.9 \%$ to $4.5 \%$ vs. $42.9 \%$ to $69.4 \%$ ), but yield responses varied considerably. Exogenous $\mathrm{GA}_{3}$ increased the yield of 'Navaho' and 'Ouachita' by $560 \%$ to $931 \%$, whereas it induced flower abortion and caused a $15 \%$ yield reduction in 'Natchez'. In the second experiment, 'Natchez' was treated with $\mathrm{GA}_{3}$ at $0,25,99$, or $198 \mathrm{~g} \cdot \mathrm{ha}^{-1}$. Budbreak increased linearly with $\mathrm{GA}_{3}$, but yield decreased exponentially with $\mathrm{GA}_{3}$ because of dose-dependent flower abortion. In the third experiment, 'Natchez' was subjected to five treatments: 1) water control; 2) $\mathbf{G A}_{3}$ spray application; 3) 6-BA spray application; 4) combined spray application of $\mathbf{G A}_{3}$ and 6-BA; and 5) sequential spray application of 6-BA at 9 days after $\mathrm{GA}_{3}$ application. Application rates were 99 and $47 \mathrm{~g} \cdot \mathrm{ha}^{-1}$ for $\mathrm{GA}_{3}$ and 6-BA, respectively. Exogenous 6-BA suppressed $\mathrm{GA}_{3}$-induced flower abortion only to a limited extent. As a result, $\mathbf{G A}_{3}$-containing treatments caused $65 \%$ to $83 \%$ yield reductions compared with the control ( 2382 vs. $410-823 \mathrm{~g} /$ plant). These results demonstrate that $\mathrm{GA}_{3}$ is a highly effective bud dormancy-breaking agent for blackberry. However, the drawback of $\mathbf{G A}_{3}$ is cultivar-dependent flower abortion, which cannot be fully mitigated by 6-BA. The use of $\mathrm{GA}_{3}$ can be an important management practice for subtropical blackberry production, but its practical implementation must consider cultivar-dependent responses.

Blackberry (Rubus L. subgenus Rubus Watson) is a deciduous berry crop grown primarily in temperate regions. In recent years, the global blackberry industry has grown significantly, driven by increased consumer demand, year-round product availability, improved cultivars, and advanced production methods (Clark and Finn, 2014). The leading producers include the United States, Serbia, Hungary, Mexico, and China (Strik et al., 2007). In the United States, blackberry is the fourth most economically important berry crop, generating \$697 million in retail sales during 2019 (California Strawberry Commission, 2019). Although blackberry production was traditionally concentrated in the West Coast of the United States, it is currently expanding to the Southeastern United States (Clark and Finn, 2014), where the production acreage increased by $52 \%$ (996 vs. 1512 ha) from 2007 to 2017 (USDA, 2017).

Adequate winter chill is a prerequisite for successful commercial production of many temperate fruit crops (Atkinson et al., 2013; Luedeling et al., 2011). For blackberry, buds must be exposed to a certain amount of winter chill to break bud dormancy in spring. This so-called chilling requirement (CR), generally calculated as cumulative hours at temperatures below $7.2{ }^{\circ} \mathrm{C}$, varies from 300 to $900 \mathrm{~h}$ among current major floricane-fruiting blackberry cultivars (Carter et al., 2006; Drake and Clark, 2000). In subtropical climates, mild winter temperatures barely satisfy the CR, resulting in incomplete bud development, poor and erratic budbreak, prolonged flowering, nonsynchronous fruit set, and, ultimately, low fruit yield (Fear and Meyer, 1993; Lin and Agehara, 2020). Therefore, commercial blackberry production in Florida is limited mostly to smallscale U-pick operations for the local market (Andersen, 2007). Bud dormancy-breaking agents must be developed to improve the productivity and consistency of subtropical blackberry production.

Bioactive gibberellins (GA), such as $\mathrm{GA}_{3}$ and $\mathrm{GA}_{4}$, have important roles in the regulation of dormancy release in many perennial crops (Horvath et al., 2003; Ionescu et al., 2016). The high efficacy of exogenous GA to induce budbreak of fruit and nut crops has been reported for sweet cherry (Prunus avium L.) (Cai et al., 2019; Vimont et al., 2018), peach (Prunus persica L.) (Chauhan et al., 1961; Donoho and Walker, 1957), pistachio (Pistacia vera L.) (Tzoutzoukou et al., 1998), and Japanese apricot (Prunus mume Sieb. et Zucc) (Zhuang et al., 2013). For blackberry, however, exogenous GA has been tested by only a few studies. Our previous study found that exogenous $\mathrm{GA}_{3}$ was highly effective for advancing the onset of budbreak and increasing the yield of 'Ouachita' blackberry grown in central Florida (Lin and Agehara, 2020).

Exogenous $\mathrm{GA}_{3}$ exerts different effects on floral development depending on the development stage (Yamaguchi et al., 2014; Yamaguchi, 2008). GA application during dormancy can induce budbreak, but application during flowering or fruit setting can result in flower or fruit abortion (Southwick and Glozer, 2000). Our previous study found that exogenous $\mathrm{GA}_{3}$ applied at the budbreak initiation stage promoted budbreak but caused a nonsignificant yield reduction in 'Natchez' blackberry, suggesting its potential negative side effects on floral development (Lin and Agehara, 2020). Cytokinins act as an antagonist of GA during floral transition in apple (Malus $\times$ domestica Borkh.) by upregulating the expression of GA degradation genes and repressing the GA signaling pathway (Li et al., 2018, 2019). In lupin (Lupinus angustifolius L.), the application of 6-benzyladenine (6-BA), a synthetic cytokinin, at 2 mm completely prevented flower abortion (Atkins and Pigeaire, 1993). Therefore, combined application of $\mathrm{GA}_{3}$ and cytokinins may provide synergistic effects. In fact, GalindoReyes et al. (2004) reported a $421 \%$ yield increase in 'Comanche' blackberry treated with both $\mathrm{GA}_{3}$ and thidiazuron, which is a cytokinin-like substance. However, individual effects of $\mathrm{GA}_{3}$ and thidiazuron were not evaluated in their study.

The goal of this study was to optimize the application protocol of $\mathrm{GA}_{3}$ as a bud dormancy-breaking method for subtropical blackberry production. We evaluated cultivar $\times$ exogenous $\mathrm{GA}_{3}$ interactions, characterized dose effects of exogenous $\mathrm{GA}_{3}$, and examined synergistic effects of $\mathrm{GA}_{3}$ and 6-BA.

\section{Materials and Methods}

Experiment sites and plant material. One field experiment was conducted at the 
University of Florida's Gulf Coast Research and Education Center in Balm, FL (lat. $27^{\circ} 76^{\prime} \mathrm{N}$, long. $82^{\circ} 23^{\prime} \mathrm{W}$; elevation $39 \mathrm{~m}$ ) during the 2017 to 2018 season (Expt. 1). Three erect, floricane-fruiting cultivars, Natchez, Navaho, and Ouachita, with estimated CRs of 300,800 to 900 , and 400 to $500 \mathrm{~h}$, respectively, were used (Drake and Clark, 2000; McWhirt, 2016). Plants were established in wooden planter boxes (length $3.7 \mathrm{~m} \times$ width $0.6 \mathrm{~m} \times$ height $0.3 \mathrm{~m}$ ) filled with aged pine bark in Apr. 2013. Each plot (experiment unit) consisted of six plants. Plants were spaced at $0.61 \mathrm{~m}$ within a row and $1.83 \mathrm{~m}$ between rows, and they were grown under a $40 \%$ black shadecloth to reduce fruit damage caused by excessive heat and rain. For trailing blackberry canes, we used a three-wire Ttrellis system with the upper, middle, and lower wires positioned at $1.5,1.1$, and $0.7 \mathrm{~m}$ from the ground, respectively. We pruned floricanes at the ground level after harvesting was completed. Newly emerged primocanes were pruned to five canes per plant and tipped when they reached the top wire. Laterals were trained and tied on the closest wires. Blackberry production and cane management practices recommended in the southeast region were followed (Fernandez and Krewer, 2008).

Two field experiments were conducted at a commercial blackberry farm located in Plant City, FL (lat. $28^{\circ} 03^{\prime} \mathrm{N}$, long. $82^{\circ} 19^{\prime} \mathrm{W}$; elevation $39 \mathrm{~m}$ ) during the 2017 to 2018 (Expt. 2) and 2018 to 2019 (Expt. 3) seasons. 'Natchez' blackberry tissue culture seedlings were transplanted in raised beds in the open field in 2015. Each plot consisted of four and five plants for Expt. 2 and Expt. 3, respectively. Plants were spaced at $0.9 \mathrm{~m}$ within rows and $3.6 \mathrm{~m}$ between rows. Beds were covered with black landscape fabric and north-south-oriented with a planting density of 3237 plants/ha. Plants were trained to a three-wire vertical trellis with the upper, middle, and lower wires positioned at 1.4, 0.9 , and $0.4 \mathrm{~m}$ from the ground, respectively. Primocanes were tipped to encourage lateral

Received for publication 17 Aug. 2020. Accepted for publication 24 Sept. 2020.

Published online 29 October 2020

This study was supported in part by the Florida Specialty Crop Block Grant Program (16SCBGPFL0041). We thank Dustin Groom for allowing us to conduct experiments on his farm and for his cooperation. We thank all members of the Horticultural Crop Physiology Lab at the Gulf Coast Research and Education Center for their technical assistance. This article was presented in the Krome memorial section at the 2020 Florida State Horticultural Society Annual Meeting.

The use of brand names and any mention or listing of commercial products or services in the publication does not imply endorsement by University of Florida nor discrimination against similar products or services not mentioned.

S.A. is the corresponding author. E-mail: sagehara@ ufl.edu.

This is an open access article distributed under the CC BY-NC-ND license (https://creativecommons.org/ licenses/by-nc-nd/4.0/). growth when they reached the lowest wire. Primocanes were then tied to the trellis and trained to loop down when they reached the top wire. Floricanes were pruned in early July, immediately after the final harvest.

Treatments and experimental design. All $\mathrm{GA}_{3}$ and 6-BA treatments in this study were prepared using ProGibb LV Plus with 5.7\% active ingredient (a.i.) (Valent Biosciences, Libertyville, IL) and MaxCel with $1.9 \%$ a.i. (Valent Biosciences). Immediately before application, treatment solutions were prepared by adding each chemical in water at the concentrations described. All treatments were applied between 9:00 and 10:00 AM using a $\mathrm{CO}_{2}$-pressured backpack sprayer (model T; Bellspray, Opelousas, LA) equipped with two flat nozzle tips (XR8002; TeeJet Technologies, Wheaton, IL) spaced $0.46 \mathrm{~m}$ apart on the spray boom. The spray pressure was $296 \mathrm{kPa}$ and the spray volume was 935 $\mathrm{L} \cdot \mathrm{ha}^{-1}$.

In Expt. 1, there were six treatments, including three cultivars (Natchez, Navaho, and Ouachita) and two $\mathrm{GA}_{3}$ application rates ( 0 and $99 \mathrm{~g} \cdot \mathrm{ha}^{-1}$ a.i. or 0 and $106 \mathrm{mg} \cdot \mathrm{L}^{-1}$ a.i.) in a factorial treatment structure. There were four replicated plots for each treatment that were arranged in a split-plot design with cultivar as the main plot factor and $\mathrm{GA}_{3}$ application rate as the subplot factor. All treatments were applied on 27 Feb. 2018. The number of accumulated chilling hours at temperatures below $7.2{ }^{\circ} \mathrm{C}$ recorded from 1 Nov. 2017 through 27 Feb. 2018 was 199 h.

In Expt. 2, treatments comprised four spray application rates of $\mathrm{GA}_{3}(0,25,99$, and $198 \mathrm{~g} \cdot \mathrm{ha}^{-1}$ a.i. or $0,27,106$, and 212 $\mathrm{mg} \cdot \mathrm{L}^{-1}$ a.i.). There were five replicated plots for each treatment that were arranged in a randomized complete block design. All treatments were applied on 20 Feb. 2018. The number of accumulated chilling hours at temperatures below $7.2{ }^{\circ} \mathrm{C}$ recorded from 1 Nov. 2017 through 20 Feb. 2018 was 227 h.

In Expt. 3, there were five treatments: water control; $\mathrm{GA}_{3}$ (spray application of $\mathrm{GA}_{3}$ ); 6-BA (spray application of 6-BA); $\mathrm{GA}_{3}+6-\mathrm{BA}$ (combined spray application of $\mathrm{GA}_{3}$ and 6-BA); and $\mathrm{GA}_{3} \rightarrow$ 6-BA (sequential spray application of 6-BA at $9 \mathrm{~d}$ after $\mathrm{GA}_{3}$ application). Application rates were 99 and $47 \mathrm{~g} \cdot \mathrm{ha}^{-1}$ a.i. for $\mathrm{GA}_{3}$ and 6-BA, respectively. There were four replicated plots for the control and three replicated plots for the other treatments that were arranged in a randomized complete block design. All treatments were applied on 19 Feb. 2019, except for the 6-BA application in the $\mathrm{GA}_{3} \rightarrow 6$-BA treatment, which was applied on 28 Feb. 2019. All treatments including the water control were supplemented with a nonionic surfactant (Regulaid; Kalo, Inc., Overland Park, KS) at $0.1 \%(\mathrm{v} / \mathrm{v})$. The number of accumulated chilling hours at temperatures below $7.2{ }^{\circ} \mathrm{C}$ recorded from 1 Nov. 2018 through 19 Feb. 2019 was $201 \mathrm{~h}$.

Floral budbreak and flower number. We selected five representative floricanes per plot before treatments. For each cane, a section containing 20 nodes, starting with the third node from the cane tip, was labeled to monitor budbreak. We counted the number of nodes with budbreak on a mostly weekly basis. Budbreak was defined as the stage at which a green tip was visible. The percentage of budbreak was calculated by dividing the number of nodes with budbreak by 20 and multiplying by 100 . Flowers at or above the popcorn stage were counted as flowers (Fernandez, 2013; Hussain et al., 2016).

Fruit yield, size, and quality. Harvesting was performed weekly between 9 May and 5 July 2018 during Expt. 1, between 7 May and 15 June 2018 during Expt. 2, and between 22 Apr. and 14 June 2019 during Expt. 3. Harvested berries were graded based on the U.S. Department of Agriculture (USDA) grade standards (USDA, 2016). Both number and fresh weight of harvested berries were recorded during Expt. 1, whereas only fresh weight was recorded during Expts. 2 and 3.

To determine fruit size and quality, the four largest (by weight) marketable berries were sampled per plot from six peak harvests during Expt. 1 and Expt. 2. For each berry, fresh weight was recorded, and berry length and width were measured across the longest and widest parts, respectively, using a digital caliper. The soluble solids concentration (SSC) was measured using a digital refractometer (PAL-1; ATAGO, Tokyo, Japan) on unfiltered juice. Fruit juice was squeezed from the entire berry with a stainless-steel garlic press.

Statistical analysis. To describe the doseresponses of dependent variables to $\mathrm{GA}_{3}$ application rates during Expt. 2, we fitted each data set to the following four models by using SigmaPlot (version 14.0; Systat Software Inc., San Jose, CA): linear Eq. [1]; quadratic Eq. [2]; exponential decay Eq. [3]; and exponential plateau Eq. [4]. The best model was selected based on the smallest corrected Akaike information criterion (AICc).

$$
\begin{gathered}
y=a+b x \\
y=a+b x+c x^{2} \\
y=a+b \exp (-k x) \\
y=a+b[1-\exp (-k x)]
\end{gathered}
$$

Data were analyzed by the generalized linear mixed model procedure (PROC GLIMMIX) in SAS statistical software (SAS 9.4; SAS Institute Inc., Cary, NC). In Expt. 1, cultivar, $\mathrm{GA}_{3}$ rate, and cultivar $\times \mathrm{GA}_{3}$ rate interaction were considered fixed effects, and replication and replication $\times$ cultivar interaction were considered random effects. In Expt. 2 and Expt. 3, treatments were considered fixed effects and replication was considered a random effect.

Continuous data (yield, berry fresh weight, berry length, and berry width) were modeled using a lognormal distribution (DIS$\mathrm{T}=\mathrm{LOGNORMAL}$ ). For the model parameter 
estimation, boundary constraints on covariance were removed (NOBOUND), and degrees of freedom for the fixed effects were adjusted by using the Kenward-Roger degrees of freedom approximation (DDFM=KR). Continuous proportion data (budbreak and SSC) were modeled with the beta distribution (DIST=BETA). If budbreak data were $0 \%$, then they were converted to $1 \%$ before the subsequent statistical analysis. Flower count data were modeled with the negative binomial distribution (DIS$\mathrm{T}=\mathrm{NEGBIN}$ ) in Expt. 1, and with the Poisson distribution (DIST $=$ POISSON) in Expt. 3. Fruit count data (fruit number) were modeled with the Poisson distribution in Expt. 1. The model selection in these tests was performed based on the smallest AICc.
Budbreak and cumulative flower count data were analyzed using a repeated measures analysis because they were collected repeatedly from the same experimental unit. To identify the appropriate covariance structure, model parameters were estimated by using maximum likelihood estimation based on Laplace approximation (METHOD=LAPLACE) with default bias-corrected sandwich estimators (EMPIRICAL=MBN) (Bowley, 2015). The appropriate covariance structure was selected based on the smallest AICc. When the appropriate covariance structure was chosen, model parameters were estimated using the restricted subject pseudolikelihood method (METHOD=RSPL), and degrees of freedom for the fixed effects were adjusted using Kenward-Roger degrees of freedom approximation (DDFM= KR2) to control the type I error (Stroup, 2018).

For continuous data, the data were backtransformed by exponentiating the least square means. For continuous proportion data and count data, data were rescaled to the original scale by using the inverse link option (ILINK) in the LSMEANS statement. Least square means comparisons were performed using the Tukey-Kramer test. Unless otherwise noted, $P$ values $<0.05$ were considered statistically significant. Backtransformed or rescaled data are reported in this study.

Table 1. Budbreak of 'Natchez', 'Navaho', and 'Ouachita' blackberry grown under subtropical climatic conditions as affected by spray application of gibberellic acid $\left(\mathrm{GA}_{3}\right)$ in the $2017-18$ season (Expt. 1). ${ }^{\mathrm{T}}$

\begin{tabular}{|c|c|c|c|c|c|}
\hline \multirow[b]{2}{*}{ Cultivar } & \multirow[b]{2}{*}{$\mathrm{GA}_{3}\left(\mathrm{~g} \cdot \mathrm{ha}^{-1}\right)$} & \multicolumn{4}{|c|}{ Budbreak (\%) } \\
\hline & & 9 Mar. (10 DAT) & 15 Mar. (16 DAT) & 23 Mar. (24 DAT) & 28 Mar. (29 DAT) \\
\hline Natchez & 99 & $46.6 \mathrm{a}$ & $54.2 \mathrm{ab}$ & $57.8 \mathrm{a}$ & $57.7 \mathrm{ab}$ \\
\hline Navaho & 0 & $0.9 \mathrm{~b}$ & $0.9 \mathrm{~d}$ & $0.9 \mathrm{c}$ & $0.9 \mathrm{c}$ \\
\hline \multirow[t]{3}{*}{ Ouachita } & 0 & $0.9 \mathrm{~b}$ & $0.9 \mathrm{~d}$ & $0.9 \mathrm{c}$ & $0.9 \mathrm{c}$ \\
\hline & 99 & $49.5 \mathrm{a}$ & $65.1 \mathrm{a}$ & $70.5 \mathrm{a}$ & $69.4 \mathrm{a}$ \\
\hline & & \multicolumn{4}{|c|}{$P$ value } \\
\hline Cultivar $x$ & & 0.0001 & 0.0001 & 0.0001 & 0.0001 \\
\hline
\end{tabular}

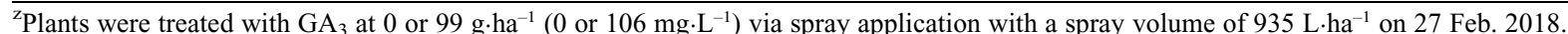

${ }^{\mathrm{y}}$ Treatment means or pooled data of each main effect $(\mathrm{n}=4)$ in a column with the same letter are not significantly different $($ Tukey-Kramer test, $P<0.05)$.

$\mathrm{DAT}=$ days after treatment.

Table 2. Flower number, fruit number, and total marketable fruit yields of 'Natchez', 'Navaho', and 'Ouachita' blackberry grown under subtropical climatic conditions as affected by gibberellic acid $\left(\mathrm{GA}_{3}\right)$ treatment in the $2017-18$ season (Expt. 1).'

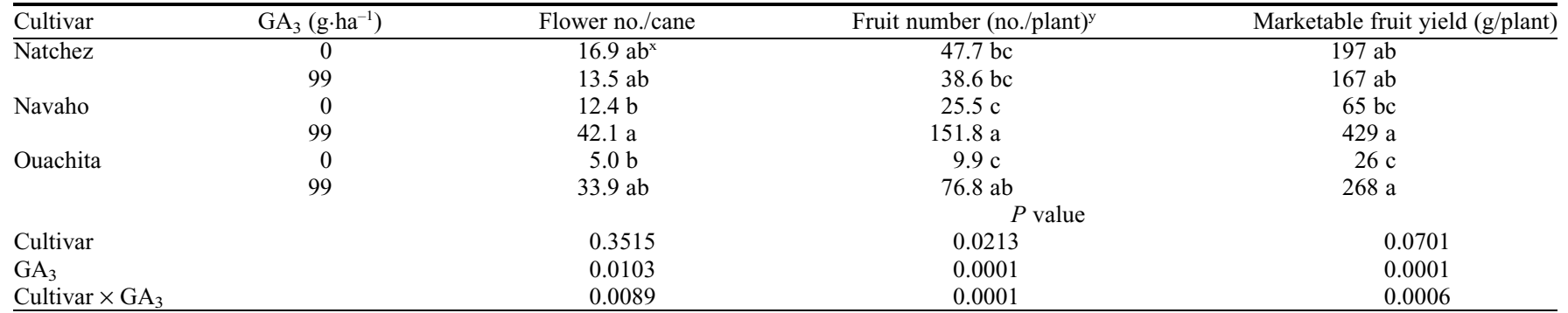

${ }^{2}$ Plants were treated with $\mathrm{GA}_{3}$ at 0 or $99 \mathrm{~g} \cdot \mathrm{ha}^{-1}\left(0\right.$ or $\left.106 \mathrm{mg} \cdot \mathrm{L}^{-1}\right)$ via spray application with a spray volume of $935 \mathrm{~L} \cdot \mathrm{ha}{ }^{-1}$ on $27 \mathrm{Feb} .2018$.

${ }^{\mathrm{y}}$ Harvest was performed nine times between 9 May and 5 July 2018.

${ }^{\mathrm{x}}$ Treatment means or pooled data of each main effect $(\mathrm{n}=4)$ in a column with the same letter are not significantly different $($ Tukey-Kramer test, $P<0.05)$.

Table 3. Berry size and soluble solids concentration (SSC) of 'Natchez', 'Navaho', and 'Ouachita' blackberry grown under subtropical climatic conditions as affected by spray application of gibberellic acid $\left(\mathrm{GA}_{3}\right)$ in the $2017-18$ season (Expt. 1). ${ }^{\mathrm{z}}$

\begin{tabular}{|c|c|c|c|c|c|}
\hline$\overline{\text { Cultivar }}$ & $\mathrm{GA}_{3}{ }^{\mathrm{y}}\left(\mathrm{g} \cdot \mathrm{ha}^{-1}\right)$ & Berry FW (g) & Berry length $(\mathrm{cm})$ & Berry width $(\mathrm{cm})$ & SSC $\left({ }^{\circ}\right.$ Brix $)$ \\
\hline Navaho & & $4.28 \mathrm{~b}$ & $2.10 \mathrm{~b}$ & $1.90 \mathrm{~b}$ & 11.2 \\
\hline Ouachita & & $4.73 \mathrm{~b}$ & $2.15 \mathrm{~b}$ & $1.99 \mathrm{ab}$ & 10.7 \\
\hline & 0 & $4.82 \mathrm{~b}$ & 2.24 & 1.98 & 10.0 \\
\hline & & \multicolumn{4}{|c|}{$P$ value } \\
\hline Cultivar & & 0.0014 & 0.0007 & 0.0083 & 0.1356 \\
\hline $\mathrm{GA}_{3}$ & & 0.0493 & 0.6176 & 0.0879 & 0.4808 \\
\hline
\end{tabular}

${ }^{\mathrm{z}}$ Because cultivar $\times \mathrm{GA}_{3}$ interaction was nonsignificant, data were pooled by each main effect. Data were collected for four largest marketable berries per plot sampled from six peak harvests. The season average data are presented.

${ }^{\text {y} P l a n t s ~ w e r e ~ t r e a t e d ~ w i t h ~} \mathrm{GA}_{3}$ at 0 or $99 \mathrm{~g} \cdot \mathrm{ha}^{-1}\left(0\right.$ or $\left.106 \mathrm{mg} \cdot \mathrm{L}^{-1}\right)$ via spray application with a spray volume of $935 \mathrm{~L} \cdot \mathrm{ha} \mathrm{p}^{-1}$ on $27 \mathrm{Feb} .2018$.

${ }^{\mathrm{x}}$ For each main effect, treatment means $(\mathrm{n}=4)$ in a column with the same letter or no letter are not significantly different $($ Tukey-Kramer test, $P<0.05)$. $\mathrm{FW}=$ fresh weight. 


\section{Results}

$G A_{3} \times$ cultivar effects on budbreak (Expt. 1). Budbreak was significantly affected by the cultivar $\times \mathrm{GA}_{3}$ interaction (Table 1). The magnitude of $\mathrm{GA}_{3}$-induced budbreak varied considerably among the tested cultivars. Compared with the respective controls, exogenous $\mathrm{GA}_{3}$ increased budbreak 10 to 14 times, 16 to 48 times, and 55 to 78 times in 'Natchez', 'Navaho', and 'Ouachita', respectively (Table 1). At 29 days after treatment (DAT), exogenous $\mathrm{GA}_{3}$ increased budbreak from $4.5 \%$ to $57.7 \%$ in 'Natchez', from $0.9 \%$ to $42.9 \%$ in 'Navaho', and from $0.9 \%$ to $69.4 \%$ in 'Ouachita'.

$\mathrm{GA}_{3} \times$ cultivar effects on fruit number and yield (Expt. 1). Flower number per cane was significantly affected by the cultivar $\times \mathrm{GA}_{3}$ interaction (Table 2). Compared with the respective controls, flower number was increased by exogenous $\mathrm{GA}_{3}$ by $240 \%$ (12.4 vs. 42.1 flowers/cane) in 'Navaho', whereas exogenous $\mathrm{GA}_{3}$ had no significant effects on 'Natchez' and 'Ouachita'.

Fruit number and marketable fruit yield showed similar responses and were significantly affected by the cultivar $\times \mathrm{GA}_{3}$ interaction (Table 2). Compared with the respective controls, exogenous $\mathrm{GA}_{3}$ increased marketable fruit yield by $560 \%$ (65 vs. $429 \mathrm{~g} / \mathrm{plant}$ ) in 'Navaho' and by $931 \%$ (26 vs. $268 \mathrm{~g} /$ plant) in 'Ouachita'; however, it caused a nonsignificant $15 \%$ yield reduction in 'Natchez' (197 vs. $167 \mathrm{~g} /$ plant).

$\mathrm{GA}_{3} \times$ cultivar effects on fruit size and quality (Expt. 1). The data presented in Table 3 and discussed here were pooled by each main effect because they were not significantly affected by the cultivar $\times \mathrm{GA}_{3}$ interaction.

Berry fresh weight was significantly affected by both cultivars and exogenous $\mathrm{GA}_{3}$ (Table 3). 'Natchez' produced $44 \%$ to $59 \%$ heavier berries than 'Ouachita' and ' $\mathrm{Na}$ vaho'. Exogenous $\mathrm{GA}_{3}$ increased berry fresh weight by $15 \%$ (4.82 vs. $5.52 \mathrm{~g} /$ berry) compared with the control. Berry length and width showed trends similar to those of berry fresh weight. Fruit SSC was not significantly affected by cultivars and exogenous $\mathrm{GA}_{3}$.

$\mathrm{GA}_{3}$ application rate effects on budbreak in 'Natchez' (Expt. 2). Budbreak was nearly zero when plants were treated with $\mathrm{GA}_{3}$ on 20 Feb. 2018. In the control, the majority of budbreak occurred by 8 DAT: budbreak slowly increased from $24.5 \%$ at 8 DAT to $31.1 \%$ at 29 DAT (Fig. 1). Budbreak was induced rapidly by exogenous $\mathrm{GA}_{3}$. At 8 DAT, budbreak showed a linear doseresponse, increasing from $24.5 \%$ to $58.3 \%$ with increasing $\mathrm{GA}_{3}$ application rates. At 15 to $29 \mathrm{DAT}$, the dose-response continued to have a similar linear increase, but the slope decreased gradually from 0.15 to 0.09 . This change in slope gradient was due to the budbreak that increased gradually in the control and to the dieback of sprouted buds that occurred only in the $\mathrm{GA}_{3}$ treatments: budbreak at $198 \mathrm{~g} \cdot \mathrm{ha}^{-1} \mathrm{GA}_{3}$ decreased from $58.3 \%$ at 8 DAT to $50.9 \%$ at 29 DAT.

$\mathrm{GA}_{3}$ application rate effects on fruit number and yield in 'Natchez' (Expt. 2). Flowering laterals without flowers was increased by exogenous $\mathrm{GA}_{3}$, and this negative side effect was maximized at $198 \mathrm{~g} \cdot \mathrm{ha}^{-1}$ (Fig. 2A). The dose-response was described by an exponential plateau model: flowering laterals without flowers increased sharply from $1.7 \%$ in the control to $55.5 \%$ at $99 \mathrm{~g} \cdot \mathrm{ha}^{-1}$ $\mathrm{GA}_{3}$ and then increased gradually to $66.4 \%$ at $198 \mathrm{~g} \cdot \mathrm{ha}^{-1} \mathrm{GA}_{3}$. According to the exponential plateau model, the estimated minimum (the control) and upper asymptote values were $2.5 \%$ and $63.6 \%$, respectively.

Flower abortion was induced by exogenous $\mathrm{GA}_{3}$ in a dose-dependent manner (Fig. 2B). Abortion occurred more severely in nondistal flowers, and some distal flowers remained intact (Fig. 3). The dose-response was described by an exponential decay: flower number per cane decreased sharply in the control from 21.8 to 5.8 at $99 \mathrm{~g} \cdot \mathrm{ha}^{-1}$ $\mathrm{GA}_{3}$ and then decreased gradually to 4.2 at $198 \mathrm{~g} \cdot \mathrm{ha}^{-1} \mathrm{GA}_{3}$. According to the exponential decay model, the estimated maximum (the control) and lower asymptote values were 21.8 and 4.1 , respectively.

Fruit number was decreased by exogenous $\mathrm{GA}_{3}$ as a result of flower abortion (Figs. 2C and 3C). The dose-response was described by exponential decay: fruit number decreased sharply in the control from 287 to 113 at $99 \mathrm{~g} \cdot \mathrm{ha}^{-1} \mathrm{GA}_{3}$ and then decreased gradually to 109 at $198 \mathrm{~g} \cdot \mathrm{ha}^{-1} \mathrm{GA}_{3}$. According to the exponential decay model, the esti-

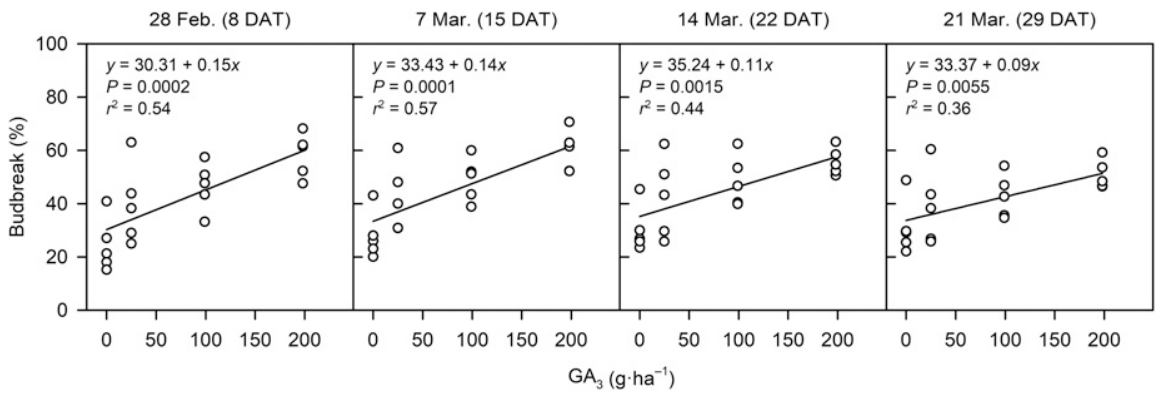

Fig. 1. Linear dose-responses of budbreak to gibberellic acid $\left(\mathrm{GA}_{3}\right)$ in 'Natchez' blackberry grown under subtropical climatic conditions in the 2017-18 season (Expt. 2). Plants were treated with $\mathrm{GA}_{3}$ at 0,25 , 99 , or $198 \mathrm{~g} \cdot \mathrm{ha}^{-1}\left(0,27,106\right.$, or $\left.212 \mathrm{mg} \cdot \mathrm{L}^{-1}\right)$ via spray application with a spray volume of $935 \mathrm{~L} \cdot \mathrm{ha}^{-1}$ on 20 Feb. 2018. Budbreak was nearly zero at the time of $\mathrm{GA}_{3}$ treatment. mated maximum (the control) and lower asymptote values were 287 and 110, respectively.

Marketable fruit yield was also decreased by exogenous $\mathrm{GA}_{3}$ in a dose-dependent manner (Fig. 2D). The dose-response was described by an exponential decay: marketable fruit yield decreased sharply in the control from $2041 \mathrm{~g} /$ plant to $477 \mathrm{~g} /$ plant at $99 \mathrm{~g} \cdot \mathrm{ha}^{-1}$ $\mathrm{GA}_{3}$ and then decreased gradually to $341 \mathrm{~g} /$ plant at $198 \mathrm{~g} \cdot \mathrm{ha}^{-1} \mathrm{GA}_{3}$. According to the exponential decay model, the estimated maximum (the control) and lower asymptote values were 2037 and $378 \mathrm{~g} /$ plant, respectively.

$\mathrm{GA}_{3}$ application rate effects on fruit size and quality in 'Natchez' (Expt. 2). Berry fresh weight showed a linear dose-response, decreasing from 13.2 to $10.4 \mathrm{~g}$ /berry with increasing $\mathrm{GA}_{3}$ application rates (Fig. 4A). No significant tested regression model was

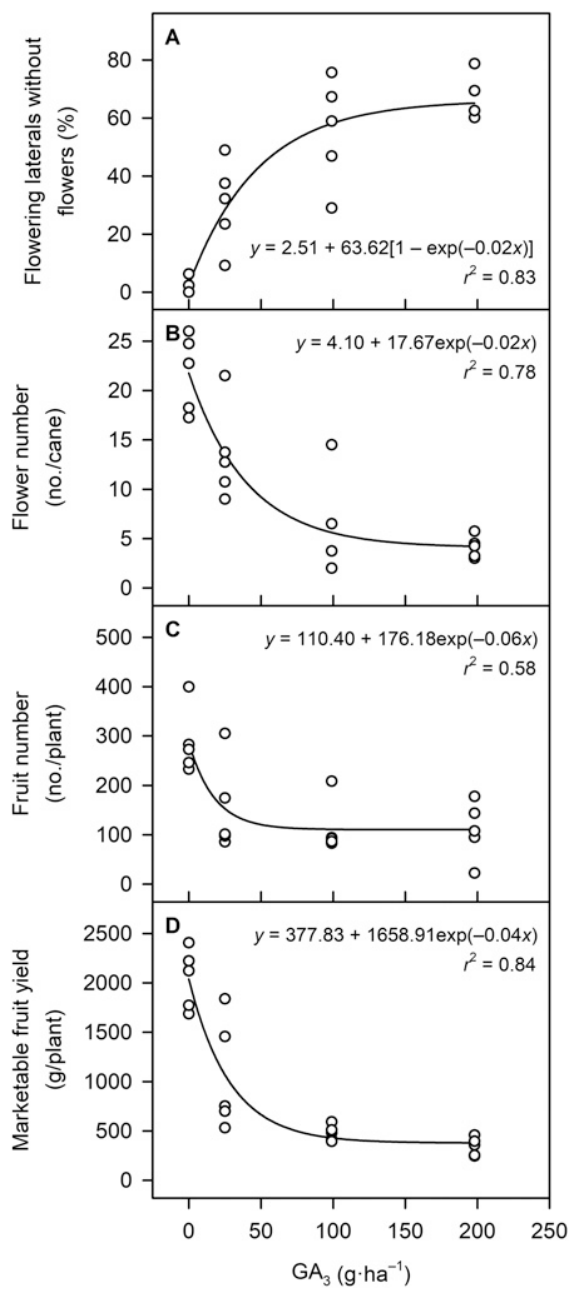

Fig. 2. Dose-responses of flowering, fruit number, and yield to spray application of $\mathrm{GA}_{3}$ in 'Natchez' blackberry grown under subtropical climatic conditions in the 2017-18 season (Expt. 2). (A) Percentage of flowering laterals without flowers. (B) Flower number per cane recorded at the end of flowering period. (C) Fruit number. (D) Marketable fruit yield. Plants were treated with $\mathrm{GA}_{3}$ at $0,25,99$, or $198 \mathrm{~g} \cdot \mathrm{ha}^{-1}$ $\left(0,27,106\right.$, or $\left.212 \mathrm{mg} \cdot \mathrm{L}^{-1}\right)$ via spray application with a spray volume of $935 \mathrm{~L} \cdot \mathrm{ha}^{-1}$ on 20 Feb. 2018. 
found to describe the relationship between berry length and the $\mathrm{GA}_{3}$ treatments (Fig. 4B). On average, berry lengths were 3.45. 3.21, 3.40 , and $3.36 \mathrm{~cm}$ at $0,25,99$, and $198 \mathrm{~g} \cdot \mathrm{ha}^{-1}$ $\mathrm{GA}_{3}$, respectively. Berry width showed a linear dose-response, decreasing from 2.66 to 2.36 $\mathrm{cm}$ with increasing $\mathrm{GA}_{3}$ application rates (Fig. 4C). In contrast, fruit SSC increased linearly from 11.8 to $12.7^{\circ} \mathrm{Brix}$ with increasing $\mathrm{GA}_{3}$ application rates (Fig. 4D).

$\mathrm{GA}_{3}$ and 6-BA effects on budbreak in 'Natchez' (Expt. 3). At $1 \mathrm{~d}$ before treatment (DBT), the budbreak was minimal, ranging from $1.4 \%$ to $3.9 \%$ in all treatments (Table 4). In the control, budbreak occurred gradually and only partially: budbreak increased from $16.4 \%$ at 9 DAT to $37.7 \%$ at 24

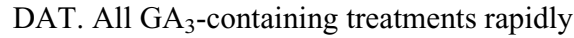
induced budbreak to a similar extent. At 9 DAT, the $\mathrm{GA}_{3}$-containing treatments showed significantly higher percentages of budbreak $(83.2 \%$ to $86.6 \%)$ than the control $(16.4 \%)$. Similar trends were observed at 16 and 24 DAT. In contrast to the $\mathrm{GA}_{3}$-containing treatments, the 6-BA treatment had minimal effects on budbreak.
$\mathrm{GA}_{3}$ and 6-BA effects on flowering and yield in 'Natchez' (Expt. 3). Plants started flowering on 15 Mar. (24 DAT) in all treatments (Table 5). The cumulative flower number per cane initially showed no significant difference among the treatments, ranging from 0.50 to 0.88 and from 2.08 to 4.73 at 24 DAT and 32 DAT, respectively. Thereafter, the control produced flowers steadily: the cumulative flower number increased from 12.20 at 38 DAT to 27.08 at 70 DAT. In contrast, no new flowering occurred in all $\mathrm{GA}_{3}$-containing treatments. As a result, flower number measured from 52 to 70 DAT was significantly lower in the $\mathrm{GA}_{3}$-containing treatments than in the control and 6-BA treatment. At the end of the flowering period (70 $\mathrm{DAT}$ ), the $\mathrm{GA}_{3}$-containing treatments produced $87 \%$ to $92 \%$ fewer flowers than the control ( 27.08 vs. $2.20-3.53$ flowers/cane).

Marketable fruit yield was significantly decreased by the $\mathrm{GA}_{3}$-containing treatments regardless of the 6-BA treatment (Table 5). The plants produced the highest marketable fruit yield in the control, and a comparable yield was obtained in the 6-BA treatment.
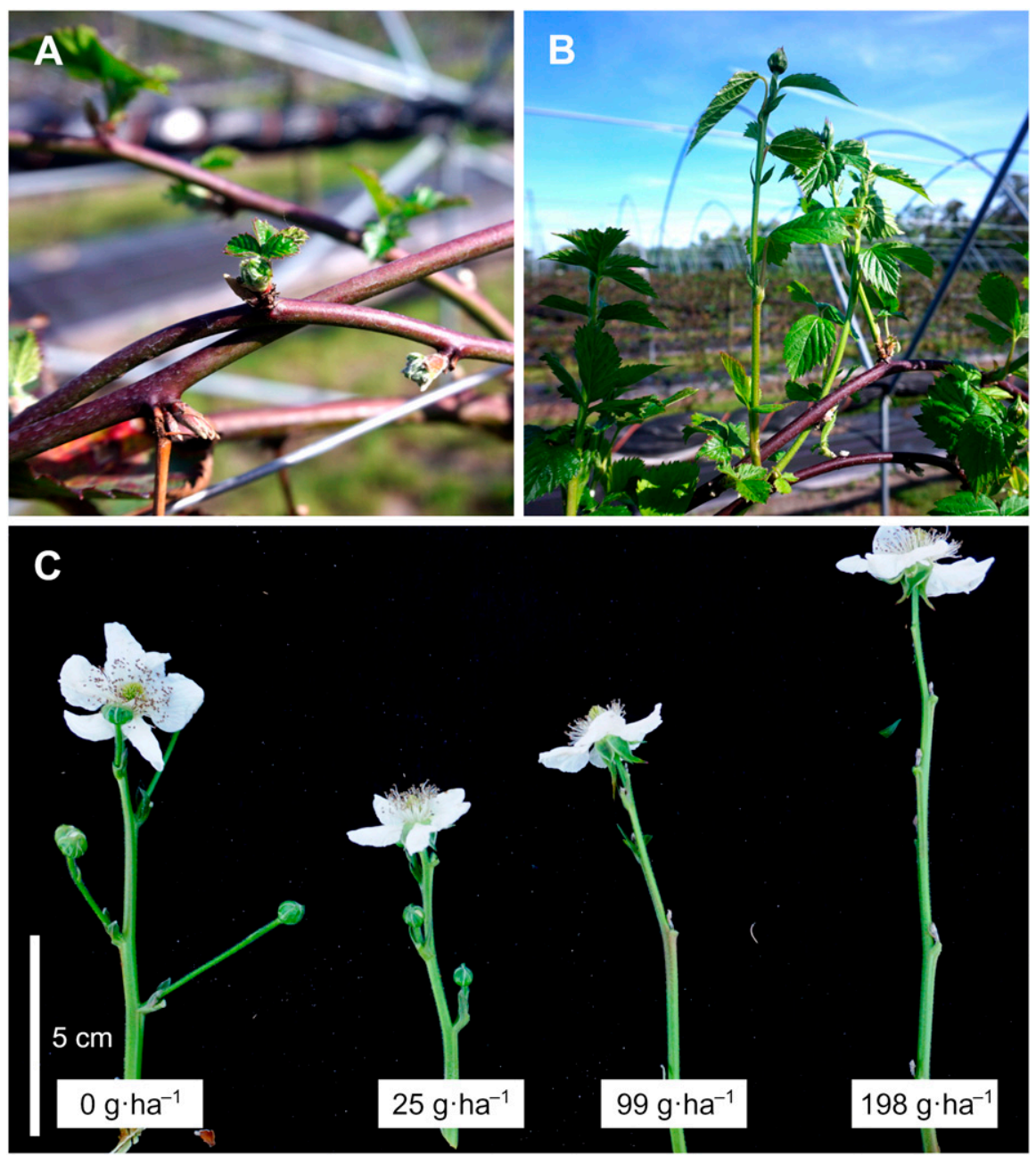

Fig. 3. Budbreak and flowering of 'Natchez' blackberry grown under subtropical climatic conditions as affected by spray application of $\mathrm{GA}_{3}$ in the 2017-18 season (Expt. 2). (A) Budbreak in the control at $15 \mathrm{~d}$ after treatment (DAT). (B) Budbreak in the $\mathrm{GA}_{3}$ treatment at $198 \mathrm{~g} \cdot \mathrm{ha}^{-1}$ at $15 \mathrm{DAT}$. (C) Flowering laterals at 29 DAT. Plants were treated with $\mathrm{GA}_{3}$ at $0,25,99$, or $198 \mathrm{~g} \cdot \mathrm{ha}^{-1}\left(0,27,106\right.$, or $\left.212 \mathrm{mg} \cdot \mathrm{L}^{-1}\right)$ via spray application with a spray volume of $935 \mathrm{~L} \cdot \mathrm{ha}^{-1}$ on $20 \mathrm{Feb} .2018$.
The $\mathrm{GA}_{3}$-containing treatments had $65 \%$ to $83 \%$ lower marketable fruit yield than the control (2382 vs. $410-823$ g/plant). Marketable fruit yield also varied between the two treatments containing both $\mathrm{GA}_{3}$ and 6-BA: the $\mathrm{GA}_{3}+6-\mathrm{BA}$ treatment had a $101 \%$ higher marketable fruit yield than the $\mathrm{GA}_{3} \rightarrow 6$-BA treatment (410 vs. $823 \mathrm{~g} /$ plant).

\section{Discussion}

Exogenous $\mathrm{GA}_{3}$ induces budbreak in floricane-fruiting blackberry cultivars. Blackberry is adapted to temperate climates, and

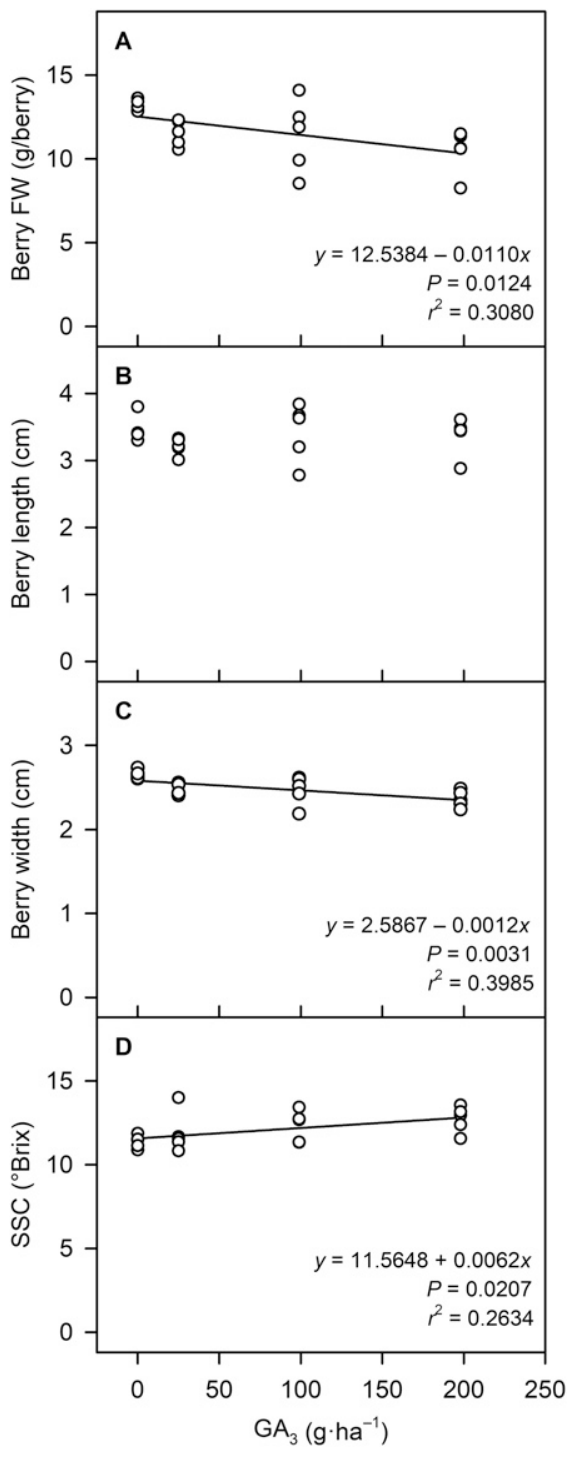

Fig. 4. Dose-responses of berry size and soluble solids concentration (SSC) to spray application of $\mathrm{GA}_{3}$ in 'Natchez' blackberry grown under subtropical climatic conditions in the 2017-18 season (Expt. 2). (A) Berry fresh weight (FW). (B) Berry length. (C) Berry width. (D) SSC. Plants were treated with $\mathrm{GA}_{3}$ at $0,25,99$, or $198 \mathrm{~g} \cdot \mathrm{ha}^{-1}\left(0,27,106\right.$, or $\left.212 \mathrm{mg} \cdot \mathrm{L}^{-1}\right)$ via spray application with a spray volume of $935 \mathrm{~L} \cdot \mathrm{ha}^{-1}$ on $20 \mathrm{Feb}$. 2018. Data were collected for four largest marketable berries per plot sampled from six peak harvests. The season average data are presented.

HortScience Vol. 55(12) December 2020 
winter chill has an important role in breaking bud dormancy. Consequently, inadequate winter chill is a major limiting factor for subtropical blackberry production (Lin and Agehara, 2020). GA are phytohormones that act as a signal to break bud dormancy in many perennial crops (Horvath et al., 2003). Major bioactive $\mathrm{GA}$ are $\mathrm{GA}_{1}, \mathrm{GA}_{3}, \mathrm{GA}_{4}$, and $\mathrm{GA}_{7}$, among which $\mathrm{GA}_{3}$ is one of the widely used plant growth regulators in horticultural production (Rodrigues et al., 2012; Yamaguchi, 2008). To our knowledge, only one study has examined budbreak induction effects of exogenous $\mathrm{GA}_{3}$ in blackberry. Galindo-Reyes et al. (2004) reported that the combined spray application of $\mathrm{GA}_{3}$ at $100 \mathrm{mg} \cdot \mathrm{L}^{-1}$ and thidiazuron at 250 $\mathrm{mg} \cdot \mathrm{L}^{-1}$ increased budbreak from $46 \%$ to $81 \%$ in 'Comanche' blackberry. However, the tested treatment was a combination of $\mathrm{GA}_{3}$ and thidiazuron, making it difficult to assess the effects of exogenous $\mathrm{GA}_{3}$. In this study, a single application of $\mathrm{GA}_{3}$ at $99 \mathrm{~g} \cdot \mathrm{ha}^{-1}(106$ $\mathrm{mg} \cdot \mathrm{L}^{-1}$ ) increased budbreak from $4.5 \%$ to $57.7 \%$ in 'Natchez', from $0.9 \%$ to $42.9 \%$ in 'Navaho', and from $0.9 \%$ to $69.4 \%$ in 'Ouachita' (Table 1), suggesting that $\mathrm{GA}_{3}$ alone can effectively induce budbreak in floricanefruiting blackberry. A linear dose-response relationship between $\mathrm{GA}_{3}$ and budbreak observed in 'Natchez' (Fig. 1) also suggests that budbreak could be further improved by optimizing the application rate.

Budbreak induction by exogenous $\mathrm{GA}_{3}$ may be associated with antagonistic interactions between $\mathrm{GA}_{3}$ and abscisic acid (ABA) (Horvath et al., 2003; Ionescu et al., 2016). In many Rosaceae fruit crops, GA production is downregulated at the onset of bud dormancy and upregulated during budbreak, whereas the exact opposite trend occurs in ABA production (Ito et al., 2019; Wen et al., 2016). Such dynamics of endogenous GA and ABA levels can be triggered by exogenous $\mathrm{GA}_{3}$ (Yue et al., 2018; Zhang et al., 2016). In addition, exogenous GA could promote budbreak indirectly by stimulating oxidative stress responses (Beauvieux et al., 2018). Zhuang et al. (2013) found that application of $100 \mu \mathrm{M} \mathrm{GA}_{4}$ to Japanese apricot increased budbreak from $20 \%$ to $60 \%$ and stimulated the production of proteins involved in oxidation-reduction responses.

Cultivar-dependent effects of exogenous $\mathrm{GA}_{3}$ on flowering and fruit production. In 'Natchez', despite significantly increased budbreak, exogenous $\mathrm{GA}_{3}$ decreased marketable fruit yield by causing severe flower abortion (Figs. 2B and 3C). Inhibitory effects of $\mathrm{GA}_{3}$ on floral development are wellrecognized in many woody perennial crops (Engin et al., 2014; Facteau et al., 1989; Hoad, 1984; Muñoz-Fambuena et al., 2012). In fact, many studies have reported the high efficacy of $\mathrm{GA}_{3}$ as a flower or fruit thinning agent for several perennial fruit crops, including apricot (Prunus armeniaca L.), Japanese plum (Prunus salicina Lindl.), nectarine (Prunus persica var. nucipersica Schneid.), and peach (García-Pallas et al., 2001; González-Rossia et al., 2006; Southwick et al., 1997; Southwick and Glozer, 2000). It is important to note, however, that
$\mathrm{GA}_{3}$ was applied at the flowering or fruit setting stage in these previous studies. In this study, flower abortion occurred even though $\mathrm{GA}_{3}$ was applied at the budbreak initiation stage, which was at least $20 \mathrm{~d}$ before flowering. This observation suggests that residual $\mathrm{GA}_{3}$ can remain above the optimum level in the tissue for an extended period, or that exogenous $\mathrm{GA}_{3}$ can induce the upregulation of $\mathrm{GA}_{3}$ production at an excessive level.

Interestingly, aborted flowers in the $\mathrm{GA}_{3}$ treatments were mostly nondistal flowers (Fig. 3). This selective $\mathrm{GA}_{3}$-induced flower abortion may indicate that absorbed $\mathrm{GA}_{3}$ is subjected to differential translocation between distal and nondistal flowers, or that the sensitivity to $\mathrm{GA}_{3}$ differs between distal and nondistal flowers.

It is also important to note that $\mathrm{GA}_{3}$ induced flower abortion was not observed in other cultivars, suggesting that this phytotoxicity is a cultivar-dependent response. In our previous study, we found that reproductive phenology of floricane-fruiting blackberry varies considerably among the three cultivars. The most remarkable difference is that 'Natchez' has a much shorter interval between budbreak and flowering than 'Navaho' and 'Ouachita' (10 vs. 25-27 d) (Lin and Agehara, 2020). This phenological difference may explain why $\mathrm{GA}_{3}$-induced flower abortion occurred only in 'Natchez'.

In 'Natchez', $\mathrm{GA}_{3}$-induced flower abortion at $99 \mathrm{~g} \cdot \mathrm{ha}^{-1}$ resulted in $15 \%, 77 \%$, and $74 \%$ yield reductions in Expt. 1, 2, and 3, respectively. The variable yield reductions by

Table 4. Budbreak of 'Natchez' blackberry grown under subtropical climatic conditions as affected by spray application of gibberellic acid $\left(\mathrm{GA}_{3}\right)$ and 6-benzyladenine (6-BA) in the 2018-19 season (Expt. 3).

\begin{tabular}{lcccc}
\hline & \multicolumn{3}{c}{ Budbreak (\%) } \\
\cline { 2 - 5 } Treatment $^{2}$ & 18 Feb. (1 DBT) & 28 Feb. (9 DAT) & 7 Mar. (16 DAT) \\
\hline Control & 2.6 & $16.4 \mathrm{~b}^{\mathrm{y}}$ & 33.7 & 88.0 \\
$\mathrm{GA}_{3}$ & 1.8 & $86.6 \mathrm{a}$ & 40.5 & 37.7 \\
$6-\mathrm{BA}$ & 3.9 & $31.5 \mathrm{ab}$ & 84.5 & 84.2 \\
$\mathrm{GA}_{3}+6$-BA & 1.4 & $83.2 \mathrm{a}$ & 80.4 & 71.3 \\
$\mathrm{GA}_{3} \rightarrow$ 6-BA & 2.4 & $85.0 \mathrm{a}$ & 0.0010 & 80.7 \\
$P$ value & 0.9797 & 0.0001 & 0.0055 \\
\hline
\end{tabular}

${ }^{\mathrm{z}}$ Treatments were as follows: control, $\mathrm{GA}_{3}$ (spray application of $\mathrm{GA}_{3}$ ), 6-BA (spray application of 6-BA), $\mathrm{GA}_{3}+6$-BA (combined spray application of GA 3 and $6-\mathrm{BA}$ ), and $\mathrm{GA}_{3} \rightarrow 6-\mathrm{BA}$ (sequential spray application of 6-BA at $9 \mathrm{~d}$ after $\mathrm{GA}_{3}$ application). Application rates were 99 and $47 \mathrm{~g} \cdot \mathrm{ha} \mathrm{a}^{-1}$ for $\mathrm{GA}_{3}$ and $6-\mathrm{BA}$, respectively, with a spray volume of $935 \mathrm{~L} \cdot \mathrm{ha}^{-1}$. All treatments were applied on $19 \mathrm{Feb}$. 2019, except for the 6-BA application in the GA $\rightarrow$ 6-BA treatment, which was applied on 28 Feb. 2019.

${ }^{\mathrm{y}}$ Means $(\mathrm{n}=3-4)$ in a column with the same letter or no letter are not significantly different (Tukey-Kramer test, $P<0.05$ ).

$\mathrm{DBT}=$ days before treatment; DAT $=$ days after treatment.

Table 5. Cumulative flower number and marketable fruit yield of 'Natchez' blackberry grown under subtropical climatic conditions as affected by spray application of gibberellic acid $\left(\mathrm{GA}_{3}\right)$ and 6-benzyladenine (6-BA) in the 2018-19 season (Expt. 3).

\begin{tabular}{|c|c|c|c|c|c|c|}
\hline \multirow[b]{2}{*}{ Treatment $^{z}$} & \multicolumn{5}{|c|}{ Cumulative flower no./cane } & \multirow[b]{2}{*}{ Marketable fruit yield (g/plant) } \\
\hline & 15 Mar. (24 DAT) & 23 Mar. (32 DAT) & 29 Mar. (38 DAT) & 12 Apr. (52 DAT) & 30 Apr. (70 DAT) & \\
\hline $\mathrm{GA}_{3}$ & 0.76 & 2.20 & 2.33 & $2.33 \mathrm{~b}$ & $2.33 \mathrm{c}$ & $615 b c$ \\
\hline $\mathrm{GA}_{3} \rightarrow 6-\mathrm{BA}$ & 0.57 & 2.08 & 2.20 & $2.20 \mathrm{~b}$ & $2.20 \mathrm{c}$ & $410 \mathrm{c}$ \\
\hline$P$ value & 0.9796 & 0.4855 & 0.0015 & 0.0001 & 0.0001 & 0.0001 \\
\hline
\end{tabular}

${ }^{\mathrm{z}}$ Treatments were as follows: control, $\mathrm{GA}_{3}$ (spray application of $\mathrm{GA}_{3}$ ), 6-BA (spray application of 6-BA), $\mathrm{GA}_{3}+6$ - $\mathrm{BA}$ (combined spray application of GA 3 and $6-\mathrm{BA}$ ), and $\mathrm{GA}_{3} \rightarrow 6-\mathrm{BA}$ (sequential spray application of 6-BA at $9 \mathrm{~d}$ after $\mathrm{GA}_{3}$ application). Application rates were 99 and $47 \mathrm{~g}^{-1} \mathrm{~h}^{-1}$ for $\mathrm{GA}_{3}$ and 6-BA, respectively, with a spray volume of $935 \mathrm{~L} \cdot \mathrm{ha}^{-1}$. All treatments were applied on $19 \mathrm{Feb}$. 2019, except for the 6-BA application in the GA $\rightarrow 6$-BA treatment, which was applied on 28 Feb. 2019.

${ }^{\mathrm{y}}$ Means $(\mathrm{n}=3-4)$ in a column with the same letter or no letter are not significantly different (Tukey-Kramer test, $P<0.05$ ).

$\mathrm{DAT}=$ days after treatment. 
exogenous $\mathrm{GA}_{3}$ may be due to the different plant performances among the three experiments. Marketable fruit yield of the control in Expt. 1 was only $8 \%$ to $10 \%$ compared with Expts. 2 and 3. Therefore, in Expt. 1, the negative effects of $\mathrm{GA}_{3}$ may have appeared less pronounced because of other yield constraints. Planting density was 8970 plants/ha in Expt. 1, but 3237 plants/ha in Expts. 2 and 3 . With the relatively high planting density, plant performance could have been limited because of increased competition for resources, thereby reducing marketable fruit yield on a per-plant basis. Plants were established in 2013 in Expt. 1, but in 2015 in Expts. 2 and 3. In Florida, the productivity of 'Natchez' is reported to decline relatively quickly compared with other cultivars. In fact, the marketable yield of 'Natchez' declined by $47 \%$ to $78 \%$ from the previous two seasons in Expt. 1, but yield decline was not observed in Expts. 2 and 3 (data not shown).

In contrast to 'Natchez', 'Navaho' and 'Ouachita' had increased marketable yield in response to exogenous $\mathrm{GA}_{3}$ by $560 \%$ and 931\%, respectively. Estimated CRs of 'Natchez', 'Navaho', and 'Ouachita' are 300,800 to 900 , and 400 to $500 \mathrm{~h}$ (Drake and Clark, 2000; McWhirt, 2016). It appears that the beneficial effects of exogenous $\mathrm{GA}_{3}$ are more pronounced in highchill cultivars. Similar results were obtained in our previous study: 'Ouachita' showed the highest yield increase in response to exogenous $\mathrm{GA}_{3}$ among the same three cultivars (Lin and Agehara, 2020). These results suggest that CRs and potential phytotoxicity are important criteria for determining the suitability of the tested cultivar for exogenous $\mathrm{GA}_{3}$.

Exogenous 6-BA does not alleviate $\mathrm{GA}_{3^{-}}$ induced flower abortion in 'Natchez'. Antagonistic interactions between cytokinins and GA occur at biosynthesis and during catabolism and have effects throughout the signaling levels during many developmental processes (Weiss and Ori, 2007). It is hypothesized that GA inhibits flowering by antagonizing the inductive effect of cytokinins on flowering in apple ( $\mathrm{Li}$ et al., 2019; Zhang et al., 2019). During floral bud formation, cytokinin production is upregulated but GA production is downregulated in apple $(\mathrm{Li}$ et al., 2019), Japanese pear (Pyrus serotina Rehd.) (Banno et al., 1985), mango (Mangifera indica L.) (Burondkar et al., 2016), and lychee (Litchi chinensis Sonn.) (Chen, 1990). In lupin, exogenous 6-BA at $2 \mathrm{~mm}$ during the flowering stage completely prevented flower abortion (Atkins and Pigeaire, 1993). In this study, mitigation of $\mathrm{GA}_{3}$-induced flower abortion by exogenous 6-BA was observed to a limited extent. Despite having similar percentages of budbreak, the $\mathrm{GA}_{3}+6$-BA treatment produced $101 \%$ higher marketable fruit yield than the $\mathrm{GA}_{3} \rightarrow 6$-BA treatment (Table 5). The $\mathrm{GA}_{3}+6$-BA treatment also had a $34 \%$ higher marketable fruit yield than the $\mathrm{GA}_{3}$ treatment, although this difference was not statistically significant. In the $\mathrm{GA}_{3} \rightarrow$ 6-BA treatment, 6-BA was applied $9 \mathrm{~d}$ after
$\mathrm{GA}_{3}$, which was likely too late to counteract $\mathrm{GA}_{3}$-induced flower abortion.

The ratio of cytokinin to GA has an important role in the regulation of bud development. For example, a high cytokinin-toGA ratio induces floral bud formation, but a low cytokinin-to-GA ratio promotes the development of vegetative buds in apple ( $\mathrm{Li}$ et al., 2018; Xing et al., 2016). Therefore, the limited efficacy of 6-BA to mitigate $\mathrm{GA}_{3}$ induced flower abortion in this study may be due to the inadequate application rate of 6BA relative to $\mathrm{GA}_{3}$. Further research is needed to test combined applications of 6 $\mathrm{BA}$ and $\mathrm{GA}_{3}$ over a wide range of rates or ratios.

Practical implications for two floricanefruiting blackberry cultivars: Navaho and Ouachita. Our results demonstrate that spray application of $\mathrm{GA}_{3}$ at $99 \mathrm{~g} \cdot \mathrm{ha}^{-1}$ is highly effective for increasing both budbreak and marketable fruit yield under subtropical climatic conditions. Exogenous $\mathrm{GA}_{3}$ has several key features that enable successful commercial implementation. First, according to the manufacturer, it has a favorable safety profile. Second, its application cost is inexpensive. Based on the price at a local major supplier of agricultural chemicals, one application of the $\mathrm{GA}_{3}$ product at $99 \mathrm{~g} \cdot \mathrm{ha}^{-1}$ costs $\approx \$ 100$ per hectare. Third, it has no negative effects on fruit development and quality. Currently, commercial blackberry production is extremely limited in subtropical climates because of inadequate winter chill. Therefore, $\mathrm{GA}_{3}$ treatment could be an important management practice for improving the adaptability of current major blackberry cultivars to subtropical climates. With the projected loss of winter chill in temperate fruit production areas (Betts et al., 2011; Luedeling et al., 2009), $\mathrm{GA}_{3}$ treatment could also become an important adaptation tool for temperate blackberry production to cope with global warming.

It is important to note that precautions should be taken when implementing the use of $\mathrm{GA}_{3}$. First, $\mathrm{GA}_{3}$ treatment has cultivarspecific phytotoxicity. Because of severe flower abortion, $\mathrm{GA}_{3}$ treatment is not recommended for 'Natchez'. Before testing $\mathrm{GA}_{3}$ treatment on new cultivars, the optimum application rate should be determined based on budbreak induction and potential phytotoxicity. Second, to avoid freeze damage to developing flowers, $\mathrm{GA}_{3}$ should be applied when the maximum chill accumulation is achieved and the risk of freeze damage is minimal.

\section{Literature Cited}

Andersen, P.C. 2007. The blackberry. University of Florida/Institute of Food and Agricultural Sciences, Gainesville, FL. 14 Aug. 2020. $<$ https:// edis.ifas.ufl.edu/hs104>

Atkins, C. and A. Pigeaire. 1993. Application of cytokinins to flowers to increase pod set in Lupinus angustifolius L. Austral. J. Agr. Res. 44:1799, doi: 10.1071/AR9931799.

Atkinson, C.J., R.M. Brennan, and H.G. Jones. 2013. Declining chilling and its impact on temperate perennial crops. Environ. Expt. Bot. 91:48-62, doi: 10.1016/j.envexpbot. 2013.02 .004$.

Banno, K., S. Hayashi, and K. Tanabe. 1985. Relationships between flower bud formation and endogenous growth regulators in Japanese Pear cultivars (Pyrus serotina Rehd.). J. Jpn. Soc. Hort. Sci. 54:15-25, doi: 10.2503/jjshs. 54.15.

Beauvieux, R., B. Wenden, and E. Dirlewanger. 2018. Bud dormancy in perennial fruit tree species: A pivotal role for oxidative cues. Front. Plant Sci. 9:657, doi: 10.3389/fpls.2018. 00657.

Betts, R.A., M. Collins, D.L. Hemming, C.D. Jones, J.A. Lowe, and M.G. Sanderson. 2011. When could global warming reach $4^{\circ} \mathrm{C}$ ? Philos. Trans. R. Soc. A Math. Phys. Eng. Sci. 369:6784, doi: 10.1098/rsta.2010.0292.

Bowley, S.R. 2015. Factorial experiments, p. 163 194. In: Plant et al. (eds.). Hitchhiker's guide to statistics in biology. GLMM ed. Kincardine, Ontario, Canada.

Burondkar, M.M., K.K. Upreti, A.R. Ambavane, S. Rajan, S.G. Mahadik, and S.G. Bhave. 2016. Hormonal changes during flowering in response to paclobutrazol application in mango cv. Alphonso under Konkan conditions. Indian J. Plant. Physiol. 21:306-311, doi: 10.1007/ s40502-016-0236-1.

Cai, B., H. Wang, T. Liu, W. Zhuang, Z. Wang, S. $\mathrm{Qu}$, and Y. Qin. 2019. Effects of gibberellins A4 on budbreak, antioxidant enzymes' activity and proline content of flower buds in sweet cherry (Prunus avium). Acta Physiol. Plant. 41:88, doi: 10.1007/s11738-019-2876-z.

California Strawberry Commission. 2019. Retail category trends report. 21 Sept. 2020. <https:// www.calstrawberry.com/en-us/market-data/ retail-category-trends $>$.

Carter, P.M., J.R. Clark, C.D. Particka, and D.Y. Crowne. 2006. Chilling response of Arkansas blackberry cultivars. J. Amer. Pomol. Soc. 60:187-197.

Chauhan, K.S., R.H. Biggs, and J.W. Sites. 1961. Influence of gibberellic acid, naphthaleneacetic acid, indole-3-acetic acid and maleic hydrazide on peach bud dormancy. Proc. Annu. Meet. Fla. State Hort. Soc. 74:374-377.

Chen, W.-S. 1990. Endogenous growth substances in xylem and shoot tip diffusate of lychee in relation to flowering. HortScience 25:314-315, doi: 10.21273/HORTSCI.25.3.314.

Clark, J.R. and C.E. Finn. 2014. Blackberry cultivation in the world. Rev. Bras. Frutic. 36:4657, doi: 10.1590/0100-2945-445/13.

Donoho, C.W. and D.R. Walker. 1957. Effect of gibberellic acid on breaking of rest period in Elberta peach. Science 126:1178-1179.

Drake, C.A. and J.R. Clark. 2000. Determination of the chilling requirement of Arkansas thornless blackberry cultivars. Student J. Dale Bump. Coll. Agr. Food Life Sci. 1:30-32.

Engin, H., Z. Gökbayrak, A. Akçal, and E. Gür. 2014. Gibberellic acid inhibits floral formation and delays flower differentiation in '0900 Ziraat' sweet cherry cultivar. Eur. J. Hort. Sci. 79:260-266.

Facteau, T.J., K.E. Rowe, and N.E. Chestnut. 1989. Flowering in sweet cherry in response to application of gibberellic acid. Scientia Hort. 38:239 245, doi: 10.1016/0304-4238(89)90071-X.

Fear, C.D. and M.-D.L. Meyer. 1993. Breeding and variation in Rubus germplasm for low winter chill requirement. Acta Hort. 352:295-304 doi: 10.17660/ActaHortic. 1993.352.42.

Fernandez, G.E. and G. Krewer. 2008. 2008 Southeast bramble production. North Carolina Coop. 
Extension. 28 Apr. 2015. <http://content.ces.ncsu.edu/ southeast-regional-caneberry-production-guide $>$.

Fernandez, G.E. 2013. Buds are tight but not for long. Coop. Extension. North Carolina Coop. Extension. 30 May 2013. <http://teamrubus. blogspot.com/2013/04/buds-are-tight-but-notfor-long.html>.

Galindo-Reyes, M.A., V.A. González-Hernández, A. Muratalla-Lúa, R.M. Soto-Hernández, and M. Livera-Muñoz. 2004. Forced production of blackberry 'Comanche' through growth regulators. Rev. Chapingo Ser. Hort. 10:205-209. (in Spanish with English abstract).

García-Pallas, I., J. Val, and A. Blanco. 2001. The inhibition of flower bud differentiation in 'Crimson Gold' nectarine with $\mathrm{GA}_{3}$ as an alternative to hand thinning. Scientia Hort. 90:265-278, doi: 10.1016/S0304-4238(01)00229-1.

González-Rossia, D., M. Juan, C. Reig, and M. Agustí. 2006. The inhibition of flowering by means of gibberellic acid application reduces the cost of hand thinning in Japanese plums (Prunus salicina Lindl.). Scientia Hort. 110:319-323, doi: 10.1016/j.scienta.2006.07.022.

Hoad, G.V. 1984. Hormonal regulation of fruit-bud formation in fruit trees. Acta Hort. 149:13-24, doi: 10.17660/ActaHortic.1984.149.1.

Horvath, D.P., J.V. Anderson, W.S. Chao, and M.E. Foley. 2003. Knowing when to grow: Signals regulating bud dormancy. Trends Plant Sci. 8:534-540, doi: 10.1016/j.tplants.2003.09.013.

Hussain, I., S.R. Roberto, I.C.B. Fonseca, A.M. de Assis, R. Koyama, and L.E.C. Antunes. 2016. Phenology of 'Tupy' and 'Xavante' blackberries grown in a subtropical area. Scientia Hort. 201:78-83, doi: 10.1016/j.scienta.2016.01.036.

Ionescu, I.A., B.L. Møller, and R. Sánchez-Pérez. 2016. Chemical control of flowering time. J. Expt. Bot. 68:369-382, doi: 10.1093/jxb/erw427.

Ito, A., P.A. Tuan, T. Saito, S. Bai, M. Kita, and T. Moriguchi. 2019. Changes in phytohormone content and associated gene expression throughout the stages of pear (Pyrus pyrifolia Nakai) Dormancy. Tree Physiol. tpz101, doi: 10.1093/treephys/tpz101.

Li, Y., D. Zhang, X. Zhang, L. Xing, S. Fan, J. Ma, C. Zhao, L. Du, and M. Han. 2018. A transcriptome analysis of two apple (Malus $\times$ domestica) cultivars with different flowering abilities reveals a gene network module associated with floral transitions. Scientia Hort. 239:269-281, doi: 10.1016/ j.scienta.2018.04.048.

Li, Y., D. Zhang, N. An, S. Fan, X. Zuo, X. Zhang, L. Zhang, C. Gao, M. Han, and L. Xing. 2019. Transcriptomic analysis reveals the regulatory module of apple (Malus $\times$ domestica) floral transition in response to 6-BA. BMC Plant Biol. 19:93, doi: 10.1186/s12870-019-1695-0.

Lin, S.-Y. and S. Agehara. 2020. Exogenous gibberellic acid advances reproductive phenology and increases early-season yield in sub- tropical blackberry production. Agronomy 10:1317, doi: 10.3390/agronomy10091317.

Luedeling, E., M. Zhang, and E.H. Girvetz. 2009. Climatic changes lead to declining winter chill for fruit and nut trees in California during 1950-2099. PLoS One 4:e6166, doi: 10.1371/ journal.pone.0006166.

Luedeling, E., E.H. Girvetz, M.A. Semenov, and P.H. Brown. 2011. Climate change affects winter chill for temperate fruit and nut trees. PLoS One 6:e20155, doi: 10.1371/journal. pone.0020155.

McWhirt, A. 2016. Blackberry variety selection. 29 Jan. 2018. <http://extension.missouri.edu/greene/ documents/Horticulture/Blackberry/BlackberryCultivars\%2C McWhirt Nov_15\%2C2016.pdf>.

Muñoz-Fambuena, N., C. Mesejo, M.C. GonzálezMas, D.J. Iglesias, E. Primo-Millo, and M. Agustí. 2012. Gibberellic acid reduces flowering intensity in sweet orange [Citrus sinensis (L.) Osbeck] by repressing CiFT gene expression. J. Plant Growth Regul. 31:529-536, doi: 10.1007/s00344-012-9263-y.

Rodrigues, C., L.P. de S. Vandenberghe, J. de Oliveira, and C.R. Soccol. 2012. New perspectives of gibberellic acid production: A review. Crit. Rev. Biotechnol. 32:263-273, doi: 10.3109/07388551.2011.615297.

Southwick, S.M., J.T. Yeager, and K.G. Weis. 1997. Use of gibberellins on 'Patterson' apricot (Prunus armeniaca) to reduce hand thinning and improve fruit size and firmness: Effects over three seasons. J. Hort. Sci. Biotechnol. 72:645652, doi: 10.1080/14620316.1997.11515554.

Southwick, S.M. and K. Glozer. 2000. Reducing flowering with gibberellins to increase fruit size in stone fruit trees: Applications and implications in fruit production. HortTechnology 10:744-751, doi: 10.21273/HORTTECH.10.4.744.

Strik, B.C., J.R. Clark, C.E. Finn, and M.P. Ban. 2007. Comprehensive crop reports worldwide blackberry production. HortTechnology 17:205-213, doi: 10.21273/HORTTECH.17.2.205.

Stroup, W.W. 2018. Analysis of non-gaussian data, p. 449-509. In: B. Glaz and K.M. Yeaters (eds.). Applied statistics in agricultural, biological, and environmental sciences. American Society of Agronomy, Crop Science Society of America, and Soil Science Society of America, Madison, WI. https://doi.org/10.2134/ appliedstatistics.2015.0081.c16.

Tzoutzoukou, C.G., C.A. Pontikis, and A. ToliaMarioli. 1998. Effects of gibberellic acid on bloom advancement in female pistachio (Pistacia vera L.). J. Hort. Sci. Biotechnol. 73:517526, doi: 10.1080/14620316.1998.11511008.

U.S. Department of Agriculture. 2016. United States standards for grades of dewberries and blackberries. 25 Apr. 2017. <www.ams.usda.gov/sites/default/ files/media/DewberriesBlackberriesStandard.pdf $>$.
U.S. Department of Agriculture. 2017. USDA/ NASS Quickstats Ad-Hoc Query Tool. 8 July 2019. <https:/quickstats.nass.usda.gov/results/ 08D195DC-7B67-32E7-9167-4314A69E6E69>.

Vimont, N., A. Schwarzenberg, M. Domijan, R. Beauvieux, M. Arkoun, J.-C. Yvin, S. Cortijo, P.A. Wigge, E. Dirlewanger, and B. Wenden. 2018. Hormonal balance finely tunes dormancy status in sweet cherry flower buds. bioRxiv 423871: doi: 10.1101/423871.

Weiss, D. and N. Ori. 2007. Mechanisms of cross talk between gibberellin and other hormones. Plant Physiol. 144:1240-1246, doi: 10.1104/ pp.107.100370.

Wen, L.H., W.J. Zhong, X.M. Huo, W.B. Zhuang, Z.J. Ni, and Z.H. Gao. 2016. Expression analysis of ABA-and GA-related genes during four stages of bud dormancy in Japanese apricot (Prunus mume Sieb. et Zucc). J. Hort. Sci. Biotechnol. 91:362-369, doi: 10.1080/ 14620316.2016.1160546.

Xing, L., D. Zhang, C. Zhao, Y. Li, J. Ma, N. An, and M. Han. 2016. Shoot bending promotes flower bud formation by miRNA-mediated regulation in apple (Malus domestica Borkh.). Plant Biotechnol. J. 14:749-770, doi: 10.1111/ pbi. 12425.

Yamaguchi, N., C.M. Winter, M.F. Wu, Y. Kanno, A. Yamaguchi, M. Seo, and D. Wagner. 2014 Gibberellin acts positively then negatively to control onset of flower formation in Arabidopsis. Science 344:638-641, doi: 10.1126/science. 1250498.

Yamaguchi, S. 2008. Gibberellin metabolism and its regulation. Annu. Rev. Plant Biol. 59:225-251, doi: 10.1146/annurev.arplant.59.032607.092804.

Yue, C., H. Cao, X. Hao, J. Zeng, W. Qian, Y. Guo, N. Ye, Y. Yang, and X. Wang. 2018. Differential expression of gibberellin- and abscisic acid-related genes implies their roles in the bud activitydormancy transition of tea plants. Plant Cell Rpt. 37:425-441, doi: 10.1007/s00299-017-2238-5.

Zhang, S., D. Zhang, S. Fan, L. Du, Y. Shen, L. Xing, Y. Li, J. Ma, and M. Han. 2016. Effect of exogenous $\mathrm{GA}_{3}$ and its inhibitor paclobutrazol on floral formation, endogenous hormones, and flowering-associated genes in 'Fuji' apple (Malus domestica Borkh.). Plant Physiol. Biochem. 107:178-186, doi: 10.1016/j.plaphy. 2016.06.005

Zhang, S., C. Gottschalk, and S. van Nocker. 2019. Genetic mechanisms in the repression of flowering by gibberellins in apple (Malus $\times$ domes tica Borkh.). BMC Genomics 20:1-15, doi: 10.1186/s12864-019-6090-6.

Zhuang, W., Z. Gao, L. Wang, W. Zhong, Z. Ni, and Z. Zhang. 2013. Comparative proteomic and transcriptomic approaches to address the active role of $\mathrm{GA}_{4}$ in Japanese apricot flower bud dormancy release. J. Expt. Bot. 64:49534966, doi: 10.1093/jxb/ert284. 